\title{
DIVERSITAS GENDER DAN NILAI PERUSAHAAN DENGAN CORPORATE SOCIAL RESPONSIBILITY SEBAGAI VARIABEL INTERVENING
}

\author{
Fitri Ella Fauziah \\ Universitas Islam Nahdlatul Ulama' Jepara \\ E-mail:v3ella@gmail.com \\ Received: April 2018; Accepted: June 2018; Available online: July 2018
}

\begin{abstract}
Abstrak
Penelitian ini bertujuan untuk mengetahui pengaruh diversitas gender dan corporate social responsibility serta untuk mengetahui pengaruh corporate social responsibility dalam memediasi hubungan antara diversitas gender dengan nilai perusahaan. Penelitian ini menggunakan data sekunder atas perusahaan yang terdaftar di BEI. Pemilihan sampel penelitian dilakukan dengan purposive sampling. Adapun teknik analisis data penelitian menggunakan bootstrapping. Temuan yang diperoleh dari penelitian ini adalah pertama, bahwa diversitasgender_CEO, CFO dan AC berpengaruh signifikan terhadap corporate social responsibility, sedangkan diversitasgender_COM tidak berpengaruh signifikan terhadap corporate social responsibility. Kedua, corporate social responsibility berpengaruh terhadap nilai perusahaan dengan mengontrol variabel diversitasgender_CEO, diversitas CFO dan $\mathrm{COM}$, selain itu juga menghasilkan koefisien yang positif. Namun demikian, corporate social responsibility tidak berpengaruh terhadap nilai perusahaan dengan mengontrol variabel diversitas gender_AC. Ketiga, corporate social responsibility memediasi hubungan antara diversitasgender_CEO dan CFO dan nilai perusahaan, sedangkan hubungan antara diversitas gender-COM dan AC dan nilai perusahaan tidak mampu dimediasi oleh corporate social responsibility.
\end{abstract}

Kata Kunci : diversitas gender, corporate social responsibility dan nilai perusahaan

\section{Abstract}

This study aims to determine the effect of gender diversity and corporate social responsibility and to know the influence of corporate social responsibility in mediating the relationship between gender diversity with company value. This study uses secondary data on companies listed on the BEI. Selection of research sample is done by purposive sampling. The research data analysis techniques using bootstrapping. The findings obtained from this research are first, that gender_CEO, CFO and AC diversity significantly influence corporate social responsibility, while gender_COM diversity has no significant effect on corporate social responsibility. Second, corporate social responsibility affects the value of the company by controlling the gender_CEO diversity variables, CFO and COM diversity, but it also produces positive coefficients. However, corporate social responsibility does not affect the firm's value by controlling the gender_AC diversity variable. Third, corporate social responsibility mediates the relationship between gender_CEO and $C F O$ diversity and corporate value, while the relationship between gender-COM and AC diversity and firm value is not capable of mediated by corporate social responsibility.

Keywords: gender diversity, corporate social responsibility and corporate value

How to Cite: Fauziah, F. E. (2018). Diversitas Gender dan Nilai Perusahaan dengan Corporate Social Responsibility sebagai Variabel Intervening. Media Ekonomi dan Manajemen, 33(2), 187-204. 


\section{PENDAHULUAN}

\section{Latar Belakang Masalah}

Diversitas gender atau keberagaman gender dalam suatu perusahaan akan mempengaruhi berbagai aspek bidang di perusahaan. Keberadaan wanita dalam dewan perusahaan telah menjadi isu yang masih diperdebatkan.Beberapa penelitian telah dilakukan dan hasil penelitianpenelitian tersebut dapat memberikan kontribusi diantaranya bagi perusahaan. Seperti yang diungkapkan oleh O'Higgins (1992) dalam Brennan et al. (1997) menyatakan bahwa keberadaan wanita dalam dewan perusahaan dapat memberikan dua keuntungan yaitu: 1) wanita bukan merupakan bagian dari old boy network yang memungkinkan mereka menjadi lebih independen, 2) wanita dapat memahami pelanggan dengan lebih baik, mengerti kebutuhan pelanggan dan peluang bagi perusahaan untuk memenuhi kebutuhan tersebut.

Adam et al. (2004) menyatakan bahwa perusahaan yang memiliki diversitas dewan beragam dapat meningkatkan efektifitas perusahaan dibandingkan dengan dewan yang homogen. Diungkapkan pula oleh Dominguez et al. (2012) bahwa keberadaan wanita dalam dewan perusahaan harus seimbang atau sedikit lebih tinggi. Penelitian terkait dengan diversitas gender dalam dewan perusahaan juga telah banyak dilakukan. Adam et al. (2009) menyatakan bahwa female directors cenderung ikut serta dalam upaya pengawasan perusahaan dibandingkan dengan male directors, sedangkan Nielson et al. (2010) menyatakan bahwa wanita yang berkedudukan sebagai directors mempengaruhi pengembangan strategi dewan melalui pengambilan keputusan. Namun demikian, bukti empiris terkait dengan hubungan diversitas gender dengan kinerja perusahaan masih beragam.

Salim (2012) menyatakan bahwa perbandingan wanita yang menduduki manajemen puncak berhubungan secara negatif terhadap kinerja keuangan serta memberikan bukti bahwa keberadaan wanita pada manajemen puncak tidak sepenuhnya dapat meningkatkan nilai perusahaan. Hal yang hampir serupa dinyatakan oleh Rose (2007), Alvarez (2007), Carter et al. (2010), Chappleet al. (2013) dan Shafique (2014), yang menyatakan bahwa tidak ada hubungan antara diversitas gender terhadap kinerja perusahaan. Ditambahkan oleh Chappleet al. (2013) bahwa terdapat sedikit bukti terkait hubungan negatif antara multiple women yang berkedudukan sebagai dewan terhadap kinerja, tetapi pada beberapa industri memiliki hubungan positif terhadap kinerja.

Hal sebaliknya dinyatakan oleh Campbell et al. (2008), Nguyen et al. (2006), Jurkus et al. (2005). Campbell et al. (2008) mengatakan bahwa diversitas gender yang diukur dengan menggunakan prosentase wanita di dewan perusahaan memiliki pengaruh positif terhadap nilai perusahaan. Diversitas gender yang besar dapat menghasilkan laba ekonomi. Didukung oleh Nguyen et al. (2006) menyatakan bahwa diversitas gender dapat meningkatkan nilai shareholder sebagaimana keberadaan wanita dalam director perusahaan yang berhubungan dengan nilai perusahaan yang lebih tinggi.Jurkuset al. (2005) mengungkapkan bahwa diversitas gender secara positif berhubungan dengan return on asset dan penilaian perusahaan.

Research gap terkait hubungan antara diversitas gender dan nilai perusahaan memberikan peluang penelitian bagi Bear et al. (2010) dan Farah (2014) untuk melakukan penelitian lebih lanjut. Bear et al. (2010) menguji dampak diversitas dewan dan komposisi gender terhadap kinerja perusahaan dan reputasi perusahaan. Hasil penelitiannya menyatakan bahwa keberadaan wanita dalam dewan perusahaan dapat memberikan kontribusi yang luas di dewan, selain itu keberadaan wanita dalam dewan berperan dalam peningkatan reputasi perusahaan melalui kegiatan CSR. Bear et al. (2010) melakukan penelitian atas perusahaan yang 
hanya bergerak di bidang industri kesehatan dan menyarankan bagi penelitian selanjutnya untuk menambah jumlah industri sebagai sampel penelitian.

Farah (2014) mereplikasi penelitian Bear et al. (2010) dengan menguji dampak diversitas dewan dan komposisi gender terhadap kinerja perusahaan dan reputasi perusahaan. Sampel penelitian meliputi perusahan-perusahaan yang memperoleh penghargaan Indonesia's Best Wealth Creator (IBWC) untuk tahun 2010-2012 dengan jumlah sampel sebanyak 73 perusahaan. Hasil penelitiannya menyatakan bahwa kinerja corporate social responsibility dan komposisi gender memiliki dampak positif terhadap reputasi perusahaan, tetapi tidak untuk diversitas dewan.

Penelitian-penelitian terdahulu mengukur diversitas gender dengan menggunakan beberapa pengukuran diantaranya adalah jumlah wanita yang berada dalam dewan (board) perusahaan seperti penelitian yang dilakukan oleh Bear et al. (2010), jumlah wanita dalam direksi perusahaan seperti penelitian yang dilakukan Farah (2014), atau mengukurnya dengan variabel dummy seperti penelitian yang dilakukan Nurrahmah et al. (2013). Penelitian ini berupaya untuk mereplikasi dan mengembangkan penelitian tersebut dengan mengukur diversitas gender tidak hanya pada dewan direksi tetapi juga diversitas gender pada dewan komisaris serta unsur pimpinan perusahaan lain yang pada dasarnya merupakan bagian dari corporate governance. Dengan demikian, penelitian ini mengukur diversitas gender dengan menghitung jumlah masing-masing wanita yang berkedudukan sebagai CEO, CFO, komisaris dan komite audit di perusahaan. Selain itu, penelitian ini akan menguji pengaruh diversitas gender, corporate social responsibility dan nilai perusahaan untuk masing-masing jenis industri seperti yang disarankan oleh Bear et al. (2010).

\section{Rumusan Masalah}

Diversitas gender dapat dikatakan sebagai proporsi wanita dalam jajaran eksekutif perusahaan. Wanita dapat berperan dalam pengambilan keputusan serta strategi-strategi yang akan dilakukan perusahaan. Campbell et al. (2008), Nguyen et al. (2006), Jurkus et al. (2005) menyimpulkan bahwa diversitas gender dalam perusahaan dapat meningkatkan nilai perusahaan. Feijoo et al. (2012) melakukan penelitian tentang hubungan komposisi gender dalam dewan perusahaan dengan corporate social responsibility. Hasil penelitiannya menyatakan bahwa tiga atau lebih wanita dalam direksi dapat menentukan pengungkapan CSR, memberikan laporan integrasi yang sedikit (less integrated reports) serta memberikan informasi strategi CSR yang lebih banyak. Hafsi et al. (2012) menyatakan bahwa gender, umur memiliki pengaruh yang signifikan terhadap kinerja sosial perusahaan. Diungkapkan pula oleh Boulouta (2012) bahwa diversitas gender dalam dewan secara signifikan berpengaruh terhadap kinerja sosial perusahaan.

Corporate social responsibility dilakukan perusahaan untuk meningkatkan image perusahaan, memenuhi harapan pengguna laporan keuangan serta memiliki tujuan jangka panjang yaitu dapat menjalin hubungan baik dengan stakeholders. Semakin banyak kegiatan corporate social responsibility yang dilakukan perusahaan, maka semakin besar image baik yang diperoleh perusahaan yang pada akhirnya akan menaikkan nilai perusahaan. Pengguna informasi perusahaan perlu melakukan analisis sebelum mengambil keputusan-keputusan yang diperlukan, diantaranya adalah nilai perusahaan. Semakin tinggi nilai perusahaan maka semakin besar pula kemungkinan perusahaan dapat menarik pengguna informasi keuangan perusahaan, terutama adalah investor. Adapun research questions yang diungkapkan dalam penelitian ini adalah: 1) apakah diversitas gender berpengaruh terhadap corporate social responsibility? 
2) apakah corporate social responsibility berpengaruh terhadap nilai perusahaan? 3) apakah corporate social responsibility memediasi hubungan antara diversitas gender dengan nilai perusahaan?

\section{Tujuan Penelitian}

Sesuai dengan research questions yang sudah diungkapkan maka tujuan penelitian dalam penelitian ini adalah: 1) Memberikan bukti empiris dan dokumentasi ilmiah terkait pengaruh diversitas gender terhadap corporate social responsibility, 2) memberikan bukti empiris dan dokumentasi ilmiah terkait pengaruh corporate social responsibility dengan nilai perusahaan, 3) memberikan bukti empiris dan dokumentasi ilmiah terkait pengaruh corporate social responsibility dalam memediasi hubungan antara diversitas gender dengan nilai perusahaan.

\section{TINJAUAN PUSTAKA}

\section{Teori Stakeholders (Stakeholders Theory)}

Perusahaan tidak hanya bertanggung jawab kepada pemiliki perusahaan (shareholders) tetapi juga harus bertanggung jawab kepada para pemangku kepentingan (stakeholders) yang meliputi pihak internal maupun eksternal yang secara langsung maupun tidak langsung memiliki pengaruh dengan perusahaan. Pihak internal dan eksternal tersebut adalah pesaing perusahaan, pemerintah, masyarakat, pemerhati lingkungan, lembaga-lembaga di luar perusahaan dan sebagainya.

Freeman (1999) dalam Freeman et al. (2002) mengatakan bahwa untuk memaksimalkan nilai shareholder melalui kerangka yang pasti, manajer juga harus lebih memperhatikan hubungan dengan stakeholders. Dengan demikian, perusahaan perlu menjaga reputasi perusahaan yang tidak hanya diukur dengan keberhasilan secara ekonomi tetapi juga harus memperhitungkan faktor-faktor lain seperti kepedulian perusahaan terhadap masalah sosial kemasyarakatan.

\section{Teori Organisasi Gender (Theory of Gendered Organizations)}

Teori Organisasi Gender memaparkan tentang diversitas gender dalam suatu organisasi. Acker (1990) dalam Nurrahmah et al. (2013) menyatakan bahwa proses gender terdiri dari lima proses interaksi yaitu : 1) pembagian konstruksi garis gender, 2) pembangunan symbol serta gambar yang menjelaskan, mengungkapkan, memperkuat dan menentang pembagian, 3) proses yang menghasilkan struktur sosial gender, 4) proses yang menghasilkan komponen indentitas individu gender, 5) Gender adalah elemen konstitutif dalam keluarga yang membantu membingkai hubungan yang mendasari struktur lain, seperti organisasi yang kompleks.

\section{Diversitas Gender}

Acker (2003) mendefinisikan gender sebagai :

"inequalities, divisions, and differences socially constructed around assumed distinctions between female and male. Gender is a basic organizing principle in social life, a principle for allocation of duties, rights, rewards, and power, including the means of violence".

Acker (2003) juga mengatakan bahwa gender meliputi wanita, pria, maskulin, feminine, wanita dan pria secara ilmiah, dalam praktik sehari-hari, dalam diskusi globalisasi, dan gender cenderung diartikan sebagai wanita. Adapun perbandingan perilaku antara wanita dan pria disimpulkan dalam penelitian yang dilakukan Croson dan Gneezy (2009) diantaranya adalah 1) wanita cenderung menolak resiko jika dibandingkan dengan pria, 2) wanita memiliki preferensi sosial yang lebih spesifik, 3) orientasi sosial wanita tidak lebih dan tidak kurang, 4) wanita memiliki preferensi sosial yang lebih lunak, 5) wanita cenderung enggan berkompetisi dibandingkan dengan pria. 
Wanita juga memiliki peran penting di perusahaan. Wanita dapat menjabat pada posisi yang dianggap penting di perusahaan diantaranya pada level komisaris, direksi, komite audit dan sebagainya. Keberagaman wanita di perusahaan dengan segala sifat dan karakter yang melekat pada diri wanita tersebut dapat berpengaruh pada pengambilan keputusan perusahaan di berbagai bidang.

\section{Corporate Social Responsibility (CSR)}

Dahlsrud (2006) menganalisis tiga puluh tujuh definisi Corporate Social Responsibility dan menyimpulkan bahwa CSR berkaitan dengan tingkat konseptual, bisnis, sosial, lingkungan dan dampak ekonomi, yang disoroti oleh stakeholders seperti pemerintah, pelanggan dan pemilik serta berkaitan dengan peraturan. Corporate Social Responsibility merupakan salah satu upaya yang dilakukan manajemen untuk meningkatkan nilai perusahaan dan memiliki tujuan jangka panjang untuk menjalin hubungan baik dengan stakeholders.Global Reporting Initiative (GRI) merupakan sebuah jaringan yang berbasis organisasi yang memfokuskan pada tiga fokus pengungkapan diantaranya pengungkapan terkait indikator ekonomi, indikator kinerja lingkungan dan indikator kinerja sosial. Penelitian ini mengukur tingkat pengungkapan CSR yang dilakukan perusahaan dengan indeks GRI tersebut dengan membagi jumlah total pengungkapan dibagi dengan jumlah item pengungkapan. Stakeholders memiliki ekspektasi yang besar kepada perusahaan atas informasi yang transparan terkait bisnis perusahaan.

\section{Nilai Perusahaan}

Rouf (2011) mendefinisikan nilai perusahaan sebagai sejumlah manfaat atau keuntungan yang diperoleh shareholders atas kepemilikan saham di perusahaan. Nilai perusahaan dicerminkan oleh harga saham, semakin tinggi harga saham maka semakin tinggi pula kontribusi yang diberikan perusahaan kepada shareholders. Sri et al. (2009) mengatakan bahwa tidak semua perusahaan menginginkan harga saham yang tinggi. Perusahaan menginginkan harga sahamnya berada pada level yang tidak terlalu tinggi maupun terlalu rendah. Harga saham yang terlalu rendah berpengaruh terhadap citra perusahaan, citra perusahaan menjadi buruk.Sebaliknya diungkapkan pula bahwa harga saham yang terlalu tinggi dapat berpengaruh terhadap penjualan harga sahamnya yaitu tidak laku dan investor tidak tertarik untuk membelinya. Beberapa proxy nilai perusahaan diantaranya adalah return on asset (ROA), return on equity (ROE), Tobin's $\mathrm{Q}$ dan price book value (PBV). Penelitian ini mengukur nilai perusahaan dengan menggunakan Price Book Value yang diadopsi dari Sri et al. (2009).Rasio ini digunakan dengan tujuan untuk mengetahui perbandingan antara nilai saham yang beredar dengan nilai buku ekuitas perusahaan.

\section{Pengembangan Hipotesis}

\section{Diversitas Gender dan Corporate Social Responsibility}

Diversitas gender menjadi isu yang masih sering dibahas di beberapa penelitian. Salah satu tujuan penelitian ini adalah untuk menguji pengaruh diversitas gender terhadap nilai perusahaan. Diversitas gender dalam penelitian ini diukur melalui beberapa proxy yaitu jumlah masing-masing wanita yang berkedudukan sebagai CEO, CFO, direksi, komisaris dan komite audit. Nurrahmah et al. (2013) mengatakan bahwa wanita yang berkedudukan dalam manajemen maupun sebagai agent berusaha untuk menghindari konflik dengan mengungkapkan informasi yang lebih banyak kepada pemegang saham. Wanita memiliki beberapa kelebihan jika dibandingkan pria, diungkapkan oleh Adam et al. (2009) menyatakan bahwa wanita dapat memberikan perspektif yang berbeda dalam pengambilan keputusan dewan, 
dewan yang memiliki diversitas yang tinggi dapat memberikan pemahaman yang lebih tentang pasar, dan peningkatan female directors dapat meningkatkan hubungan atau peluang networking.

CEO merupakan jabatan yang tertinggi di perusahaan, diversitas gender dalam CEO perusahaan diharapkan dapat memberikan perubahan dalam organisasi. Nurrahmah et al. (2013) mengatakan bahwa memiliki gaya kepemimpinan yang luwes, kepercayaan, team work dan kontrol atas struktur yang ketat serta wanita cenderung untuk mendengarkan, memberikan motivasi dan melakukan hal lebih baik dibandingkan pria. CFO terlibat dalam penyusunan laporan perusahaan, sehingga keberadaan wanita sebagai CFO dalam perusahaan secara tidak langsung diharapkan mempengaruhi keputusan untuk kegiatan corporate social responsibility. Sedangkan, komisaris dan komite audit bekerja sama untuk melakukan pengawasan kegiatan di perusahaan dan Adam et al. (2009) mengungkapkan bahwa wanita yang berkedudukan dalam direksi cenderung ikut serta dalam komite pengawasan. Keterkaitan diversitas gender dalam manajemen perusahaan dengan aktivitas corporate social responsibility, dinyatakan oleh Feijooet al. (2012) yang melakukan penelitian tentang hubungan komposisi gender dalam dewan perusahaan dengan corporate social responsibility. Hasil penelitiannya menyatakan bahwa tiga atau lebih wanita dalam direksi dapat menentukan pengungkapan CSR, memberikan laporan integrasi yang sedikit (less integrated reports) serta memberikan informasi strategi CSR yang lebih banyak. Dengan demikian, hipotesis yang diungkapkan dalam penelitian ini adalah:

$\mathrm{H}_{1}$ : Diversitas gender berpengaruh terhadap corporate social reponsiblity

\section{Corporate Social Responsibility dan Nilai Perusahaan}

Isu yang terkait dengan lingkungan banyak menjadi sorotan dan dianggap sebagai kebutuhan oleh perusahaan.Hal tersebut dilakukan perusahaan untuk menumbuhkan image yang baik di mata stakeholders. Perusahaan tidak hanya berorientasi pada keuntungan yang diperoleh tetapi juga harus memperhatikan dimensi-dimensi yang lain diantaranya sosial, ekonomi dan lingkungan. Corporate Social Responsibility merupakan bentuk perhatian dan kepedulian perusahaan terhadap lingkungan yang juga dapat ditujukan untuk meningkatkan nilai perusahaan.

Semakin banyak kegiatan Corporate Social Responsibility diharapkan dapat meningkatkan nilai perusahaan.Hal ini didukung penelitian yang dilakukan oleh Puspaningsih dan Isna (2017) dan Gregory et al. (2012) yang mengungkapkan bahwa Corporate Social Responsibility memiliki pengaruh terhadap nilai perusahaan. Variabel corporate social responsibility diduga memiliki pengaruh terhadap nilai perusahaan dengan mengontrol variabel diversitas gender_CEO, diversitas gender_CFO dan diversitas gender_COM. Keterkaitan antara diversitas gender dengan nilai perusahaan telah dibuktikan melalui penelitian yang dilakukan oleh Campbell et al. (2008), Huan et al. (2011), Jurkus et al. (2005) dan Smith et al. (2005) yang menyatakan bahwa diversitas gender memiliki pengaruh positif terhadap nilai perusahaan. Selain itu, menurut Adams dan Ferreira (2009) dalam Smith et al. (2005) mengungkapkan bahwa keanggotaan wanita dalam dewan perusahaan menunjukkan tingkat kehadiran keterlibatan dalam monitoring komite yang lebih tinggi.

$\mathrm{H}_{2}$ : Corporate Social Responsibility berpengaruh terhadap nilai perusahaan 
Corporate Social Responsibility dalam memediasi hubungan antara diversitas gender dengan nilai perusahaan.

Beberapa penelitian berupaya untuk mengaitkan antara diversitas gender dengan nilai perusahaan, di antaranya adalah Campbell et al. (2008) yang mengatakan bahwa diversitas gender berpengaruh positif terhadap nilai perusahaan serta dapat menghasilkan laba ekonomi, Huan et al. (2011) mengungkapkan bahwa keberadaan wanita dalam komite audit berpengaruh terhadap Cumulative Abnormal Return (CAR). Didukung pula dengan pernyataan Jurkuset al. (2005) mengungkapkan bahwa diversitas gender secara positif berhubungan dengan return on asset dan nilai perusahaan.

\section{Kegiatan Corporate Social} Responsibility yang dilakukan perusahaan dapat meningkatkan nilai perusahaan (Puspaningsih dan Isna (2017) dan Gregory et al. (2012)). Semakin banyak kegiatan corporate social responsibility yang dilakukan perusahaan, maka semakin besar image baik yang diperoleh perusahaan yang pada akhirnya akan menaikkan nilai perusahaan. Namun demikian, penelitian ini berupaya untuk menguji pengaruh antara diversitas gender, corporate social responsibility dan nilai perusahaan. Seperti yang diungkapkan oleh Feijoo et al. (2012) bahwa keberagaman dalam dewan perusahaan menentukan pengungkapan corporate social responsibility perusahaan. Dengan demikian, diharapkan Corporate Social Responsibility dapat memediasi hubungan antara diversitas gender dengan nilai perusahaan. Hipotesis yang diungkapkan dalam penelitian ini adalah:

$\mathrm{H}_{3}$ : Diversitas Gender berpengaruh terhadap nilai perusahaan melalui Corporate Social Responsibility

\section{Kerangka Pemikiran Penelitian}

Kerangka pemikiran penelitian dijelaskan pada Gambar 1.

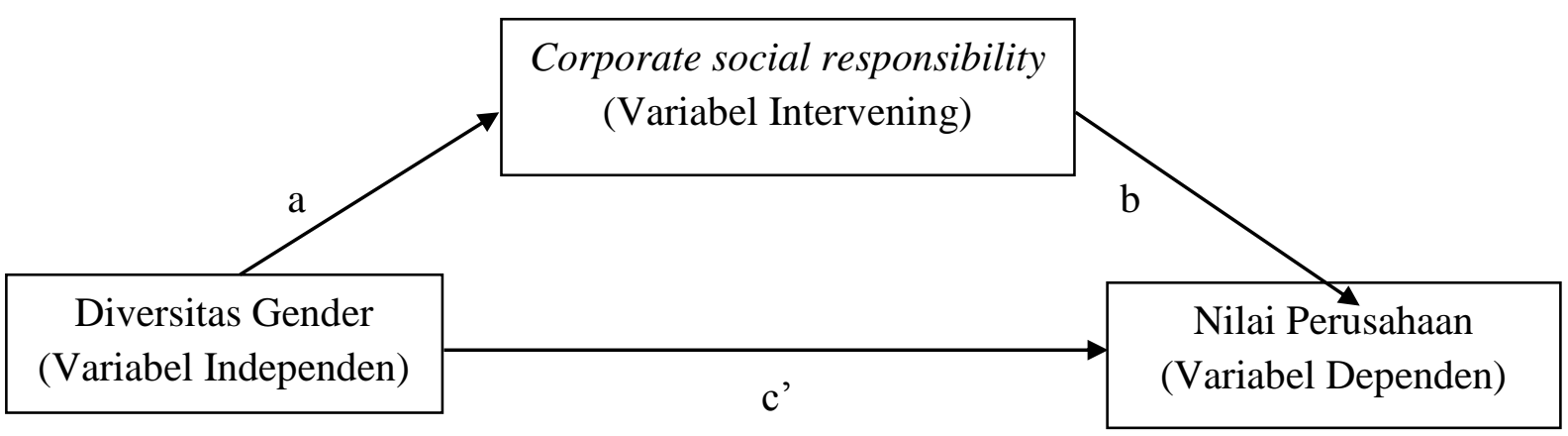

Gambar 1. Kerangka Pemikiran Penelitian

\section{Metode Penelitian}

\section{Populasi dan Sampel Penelitian}

Penelitian ini menggunakan data sekunder yaitu laporan keuangan dan annual report perusahaan yang listing di BEI untuk periode tahun 2010-2013.

Adapun sampel penelitian diambil dengan menggunakan teknik purposive sampling. Kriteria yang digunakan dalam pengambilan sampel penelitian ini adalah :
1. Perusahaan yang menerbitkan laporan keuangan tahun 2011-2013.

2. Perusahaan yang memiliki kelengkapan informasi terkait dengan informasi diversitas gender.

3. Perusahaan yang memiliki kelengkapan informasi terkait dengan informasi nilai perusahaan.

4. Perusahaan yang mempunyai kelengkapan data terkait dengan CSR 


\section{Variabel yang Diamati}

Variabel yang digunakan dalam penelitian ini meliputi :

a. Variabel Dependen

Variabel dependen dalam penelitian ini adalah nilai perusahaan yang diukur dengan Price to Book Value (PBV).Price to Book Value menunjukkan seberapa besar nilai buku saham perusahaan dihargai oleh pasar, sehingga semakin besar nilai PBV maka semakin besar pula penilaian pasar atas perusahaan tersebut. Penelitian ini menggunakan PBV yang diadopsi dari Sri et al. (2009) dengan rumus sebagai berikut :

$$
P B V=\frac{\text { Harga Saham }}{B V}
$$

Book Value diperoleh dengan membagi total asset bersih (Aset Hutang) dengan total saham yang beredar.

$$
B V=\frac{\text { Total Ekuitas }}{\text { Jumlah Saham }}
$$

b. Variabel Independen

Variabel independen dalam penelitian ini adalah diversitas gender. Diversitas gender diukur dengan menghitung jumlah masing-masing wanita yang berkedudukan sebagai $\mathrm{CFO}$, CEO, komite audit (AC) dan komisaris $(\mathrm{COM})$ di masing-masing perusahaan.

c. Variabel Intervening

Variabel intervening dalam penelitian ini adalah corporate social responsibility (CSR) yang diukur dengan menggunakan indeks dalam Global Reporting Indeks (GRI).Total pengungkapan perusahaan dibagi dengan jumlah pengungkapan.

\section{Teknik Pengumpulan Data}

Data yang digunakan dalam penelitian ini berupa data sekunder yaitu annual report dan laporan keuangan perusahaan-perusahaan yang listing di BEI. Adapun pengumpulan data diperoleh dari www.idx.co.id, serta dari website masing-masing perusahaan.

\section{HASIL PENELITIAN \\ Statistik Deskriptif}

Berdasarkan pada hasil statistik deskriptif di Tabel 1 dapat diketahui bahwa mean dari jumlah wanita yang berkedudukan sebagai CEO dan CFO perusahaan sebesar 0.08 dan 0.19 . Hal ini menunjukkan bahwa masih minimnya jumlah wanita yang berada di jajaran manajerial perusahaan.Adapun standar deviasi untuk kedua posisi tersebut adalah sebesar 0.266 dan 0.390. Nilai deviasi standar tersebut menunjukkan angka yang lebih besar dibandingkan dengan mean nya. Hal ini menunjukkan bahwa terdapat perbedaan jumlah wanita yang menjabat dalam manajemen perusahaan yang tidak terlalu besar.Nilai maksimum jumlah wanita sebagai CEO dan CFO perusahaan sebesar 1 orang, sedangkan nilai minimum nya adalah 0 .

Nilai rata-rata (mean) komisaris (COM) dan komite audit (AC) menunjukkan angka sebesar 0.39 dan 0.57. Nilai tersebut mengindikasikan bahwa jumlah wanita yang menjabat sebagai komisaris dan komite audit masih di kisaran sedang atau cukup. Standar deviasi untuk kedua posisi tersebut adalah sebesar 0.691 dan 0.787. Nilai deviasi standar tersebut menunjukkan angka yang lebih besar dibandingkan dengan mean nya. Hal ini menunjukkan bahwa terdapat perbedaan jumlah wanita yang menjabat sebagai komisaris dan komite audit yang tidak terlalu besar. Nilai maksimum jumlah wanita sebagai komisaris dan komite audit perusahaan sebesar 3 orang, sedangkan nilai minimum nya adalah 0 .

Nilai rata-rata (mean) pengungkapan CSR perusahaan menunjukkan angka sebesar 11.74 yang berarti bahwa dari 210 sampel penelitian rata-rata hanya mampu mengungkapkan aktivitas CSR yang dilakukan sebesar 11 item, dengan nilai minimum pengungkapan sebesar 2.5 dan nilai maksimum 31.6. Namun demikian nilai standar deviasi yang dihasilkan sebesar 6.53, lebih kecil jika dibandingkan dengan nilai rata-rata (mean).Hal ini 
berarti bahwa terdapat perbedaan jumlah pengungkapan CSR perusahaan satu dengan perusahaan lainnya yang relatif kecil.

Nilai rata-rata (mean) price book value (PBV) menunjukkan angka sebesar 3.18 dengan nilai minimum sebesar -22.93 dan nilai maksimum 59.14. Adapun nilai standar deviasi menunjukkan angka yang lebih besar jika dibandingkan dengan nilai rata-rata (mean). Hal ini berarti bahwa terdapat perbedaan price book value (PBV) perusahaan satu dengan perusahaan lainnya yang cukup besar.

\section{Hasil Pengujian Normalitas Data}

Hasil pengujian normalitas data menunjukkan bahwa data penelitian tidak berdistribusi normal, maka penelitian ini menggunakan teknik bootstrapping dalam SPSS.Teknik bootstrapping termasuk dalam kategori pendekatan nonparametrik yang digunakan untuk mengestimasi pengaruh ukuran dan menguji hipotesis tanpa harus memenuhi asumsi bentuk distribusi variabel atau distribusi sampling statistik (Efron dan Tibshirani, 1993; Mooney dan Duval, 1993; dalam Preacher dan Hayes, 2004).

Preacher dan Hayes (2004) juga mengungkapkan bahwa bootstrapping dilakukan dengan mengambil sampel dalam jumlah yang besar dari $n$ (n merupakan jumlah sampel asli) data, penggantian sampling, dan menghitung pengaruh tidak langsung. Hair et al. (1998) menyatakan bahwa pendekatan ini merupakan pendekatan nonparametrik yang sering disebut sebagai resampling. Penelitian ini melakukan pengujian dengan melakukan resampling sampai 5000 kali.

Dalam metode bootstrap, pengaruh mediasi corporate social responsibility dalam hubungan antara diversitas gender terhadap nilai perusahaan dapat diestimasi melalui Confidence Interval (CI) dengan melihat batas bawah (lower bound) dan batas atas (upper bound). Nilai batas bawah maupun batas atas baik positif maupun negatif dan batas keduanya tidak melewati angka nol, maka dapat dinyatakan signifikan (Hayes, 2009).

Adapun hasil bootstrapping untuk corporate social responsibility dalam memediasi hubungan antara masingmasing diversitas gender yang menjabat sebagai CEO, CFO, COM dan AC dengan nilai perusahaan dipaparkan pada Tabel 2 .

Berdasarkan pada Tabel 2, terlihat bahwa c merupakan total effect variabel independen (X) yaitu diversitas gender terhadap variabel dependen (Y) yaitu nilai perusahaan. Total effect variabel diversitasgender_CEO terhadap nilai perusahaan menunjukkan nilai koefisien sebesar negatif 0.2194 dan tidak signifikan pada 0.9002. Total effect variabel diversitasgender_CFO terhadap nilai perusahaan menunjukkan nilai koefisien sebesar negatif 1.3153 dan tidak signifikan pada 0.2698. Total effect variabel diversitasgender_COM terhadap nilai perusahaan menunjukkan nilai koefisien sebesar negatif 1.0497 dan tidak signifikan pada 0.1180 . Total effect variabel diversitasgender_AC terhadap nilai perusahaan menunjukkan nilai koefisien sebesar positif 0.8366 dan signifikan pada 0.0014 .

Pengaruh langsung variabel independen (X) yaitu diversitas gender terhadap variabel dependen $(\mathrm{Y})$ yaitu nilai perusahaan dengan mengontrol variabel mediasi (M) yaitu corporate social responsibilityyang disimbolkan dengan c'. Pengaruh langsung variabel diversitasgender_CEO terhadap nilai perusahaan dengan mengontrol corporate social responsibility memberikan nilai koefisien sebesar positif 0.3174 dan tidak signifikan pada 0.8557 .

Pengaruh langsung variabel diversitasgender_CFO terhadap nilai perusahaan dengan mengontrol corporate social responsibility memberikan nilai koefisien sebesar negatif 0.9453 dan tidak signifikan pada 0.4276. Pengaruh langsung variabel diversitasgender_COM terhadap nilai perusahaan dengan mengontrol corporate social responsibility memberikan nilai koefisien sebesar negatif 0.9676 dan tidak 
signifikan pada 0.1459, sedangkan pengaruh langsung variabel diversitasgender_AC terhadap nilai perusahaan dengan mengontrol corporate social responsibility memberikan nilai koefisien sebesar positif 0.7009 dan signifikan pada 0.162 .

Pengaruh variabel independen (X) yaitu diversitas gender terhadap variabel mediasi (M) yaitu corporate social responsibility disimbolkan dengan a. Pengaruh variabel diversitasgender_CEO terhadap corporate social responsibility menghasilkan koefisien sebesar negatif 3.2045 dan signifikan pada level $10 \%$ yaitu 0.0592. Pengaruh variabel diversitasgender_CFO terhadap corporate social responsibility menghasilkan koefisien sebesar negatif 2.3426 dan signifikan pada 0.0431. Pengaruh variabel diversitasgender_COM terhadap corporate social responsibility menghasilkan koefisien sebesar negatif 0.5123 dan tidak signifikan pada 0.4350 . Pengaruh variabel diversitasgender_AC terhadap corporate social responsibility menghasilkan koefisien sebesar positif 1.6763 dan signifikan pada 0.000

Pengaruh variabel mediasi (M) yaitu corporate social responsibility terhadap variabel dependen (Y) yaitu nilai perusahaan dengan mengontrol variabel independen $(\mathrm{X})$ yaitu diversitas gender dilambangkan dengan $\mathrm{b}$. Pengaruh variabel corporate social responsibility terhadap variabel nilai perusahaan dengan mengontrol variabel diversitasgender_CEO memberikan koefisien sebesar positif 0.1675 dan signifikan pada 0.0192 . Pengaruh variabel corporate social responsibility terhadap variabel nilai perusahaan dengan mengontrol variabel diversitasgender_CFO memberikan koefisien sebesar positif 0.1579 dan signifikan pada 0.0271 .

Pengaruh variabel corporate social responsibility terhadap variabel nilai perusahaan dengan mengontrol variabel diversitasgender_COM memberikan koefisien sebesar positif 0.1603 dan signi- fikan pada 0.0232. Pengaruh variabel corporate social responsibility terhadap variabel nilai perusahaan dengan mengontrol variabel diversitas gender_AC memberikan koefisien sebesar positif 0.0809 dan tidak signifikan pada 0.2988. Adapun hasil output indirect effect variabel independen terhadap variabel dependen (Y) melalui variabel mediasi (M) disajikan pada Tabel 3.

Pengaruh tidak langsung variabel independen (X) yaitu diversitas gender terhadap variabel dependen $(\mathrm{Y})$ yaitu nilai perusahaan melalui variabel mediasi (M) yaitu corporate social responsibility dilambangkan dengan ab. Dalam hal ini ab merupakan hasil perkalian antara koefisien a dan koefisien b. Pengaruh tidak langsung untuk semua variabel diversitas gender terhadap nilai perusahaan melalui corporate social responsibility menghasilkan nilai koefisien mediasi negatif dan tidak signifikan.

Penelitian ini menggunakan teknik bootstrapping yang memberikan nilai estimasi indirect effect variabel independen (X) terhadap variabel dependen (Y) melalui variabel mediasi (M) dengan standar error dan nilai confidence level (CI) $95 \%$. Hasil bootstrapping menunjukkan bahwa corporate social responsibility dapat memediasi hubungan antara diversitasgender_CEO dan diversitasgender_CFO dengan nilai perusahaan. Hal ini dapat diketahui dari nilai confidence level (CI) menunjukkan nilai Lower Level (LL) dan Upper Level (UP) yang tidak melewati angka nol baik positif maupun negatif. Nilai Lower Level (LL) dan Upper Level (UP) untuk diversitasgender_CEO adalah sebesar negatif 1.2065 dan negatif 0.0767 , sedangkan untuk diversitas gender adalah negatif 0.8857 dan negatif 0.0276 . Namun, hal sebaliknya yang dapat disimpulkan bahwa corporate social responsibility tidak mampu memediasi hubungan antara diversitasgender_COM dan diversitasgender_AC dengan nilai perusahaan karena nilai confidence level $(\mathrm{CI})$ menunjukkan nilai Lower Level (LL) dan Upper Level (UP) yang melewati angka nol. 
Tabel 1. Statistik Deskriptif

\begin{tabular}{lrrrrrr}
\hline \multicolumn{7}{c}{ Descriptive Statistics } \\
\hline CEO & 210 & 1 & 0 & 1 & .08 & .266 \\
\hline CFO & 210 & 1 & 0 & 1 & .19 & .390 \\
\hline COM & 210 & 3 & 0 & 3 & .39 & .691 \\
\hline AC & 210 & 3 & 0 & 3 & .57 & .787 \\
\hline CSR & 210 & 29.1139 & 2.5316 & 31.6456 & 11.742013 & 6.5347145 \\
\hline PBV & 210 & 82.0792 & -22.9300 & 59.1492 & 3.189473 & 6.7018427 \\
\hline $\begin{array}{l}\text { Valid N } \\
\text { (listwise) }\end{array}$ & 210 & & & & & \\
\hline
\end{tabular}

Sumber : Data sekunder yang diolah

Tabel 2 . Koefisien Non-standardized Regression dan Signifikansi Model dari Total Effect (c), Direct Effect (c'), dan Indirect Path (a) dan (b)

\begin{tabular}{llcccc}
\hline & Model & $\mathrm{b}(\mathrm{c}), p$ & $\mathrm{~b}\left(\mathrm{c}^{\prime}\right), p$ & $\mathrm{~b}(\mathrm{a}), p$ & $\mathrm{~b}(\mathrm{~b}), p$ \\
\hline \multirow{4}{*}{ CSR } & DG_CEO/NP & $-0.2194,0.9002$ & $0.3174,0.8557$ & $-3.2045,0.0592^{* *}$ & $0.1675,0.0192^{*}$ \\
\cline { 2 - 6 } & DG_CFO/NP & $-1.3153,0.2698$ & $-0.9453,0.4276$ & $-2.3426,0.0431^{*}$ & $0.1579,0.0271^{*}$ \\
\cline { 2 - 6 } & DG_COM/NP & $-1.0497,0.1180$ & $-0.9676,0.1459$ & $-0.5123,0.4350$ & $0.1603,0.0232^{*}$ \\
\cline { 2 - 6 } & DG_AC/NP & $0.8366,0.0014 *$ & $0.7009,0.0162^{*}$ & $1.6763,0.0000^{*}$ & $0.0809,0.2988$ \\
\hline
\end{tabular}

Sumber : Data sekunder yang diolah

$* \mathrm{p}<0.05, * * \mathrm{p}<0.10$

Keterangan : CSR : Corporate Social Responsibility, DG_CEO : DiversitasGender_CEO, DG_CFO : DiversitasGender_CFO, DG_COM : Diversitas Gender_COM, DG_AC : DiversitasGender_AC, NP : Nilai Perusahaan.

Tabel 3. Koefisien Non-standardized Regression dari Indirect Effect (ab) dengan Confidence Interval (CI) untuk Bootstrap 95\%

\begin{tabular}{llcc}
\hline & Model & $\mathrm{b}(\mathrm{ab}), p,[\mathrm{CI}]$ & Bootstrap $[\mathrm{CI}] \mathrm{LL}, \mathrm{UL}$ \\
\hline \multirow{4}{*}{ CSR } & DG_CEO/NP & $-0.5368,0.1602,[-1.2860,0.2124]$ & {$[-1.2065,-0.0767]$} \\
\cline { 2 - 4 } & DG_CFO/NP & $-0.3700,0.1539,[-0.8786,0.1386]$ & {$[-0.8857,-0.0276]$} \\
\cline { 2 - 4 } & DG_COM/NP & $-0.0821,0.4940,[-0.3174,0.1532]$ & {$[-0.2975,0.1286]$} \\
\cline { 2 - 4 } & DG_AC/NP & $-0.1433,0.2236,[-0.3742,0.0875]$ & {$[-0.3787,0.0324]$} \\
\hline
\end{tabular}

Sumber : Data sekunder yang diolah

Keterangan : CSR : Corporate Social Responsibility, DG_CEO : Diversitas Gender_CEO, DG_CFO : Diversitas Gender_CFO, DG_COM : Diversitas Gender_COM, DG_AC : Diversitas Gender_AC, NP : Nilai Perusahaan.

\section{Pembahasan \\ Pengaruh Diversitas Gender Terhadap Corporate Social Responsibility}

Dalam hal ini, diversitas gender meliputi jumlah wanita yang memiliki kedudukan sebagai CEO, CFO, komisaris (COM) dan komite audit (AC) dalam perusahaan.Berdasarkan pada hasil yang ditunjukkan pada tabel 2 bahwa variabel diversitasgender_CEO, diversitasgender-
_CFO dan diversitasgender_AC berpengaruh signifikan terhadap corporate social responsibility, sedangkan variabel diversitasgender_COM tidak berpengaruh signifikan terhadap corporate social responsibility.

Penelitian ini memberikan hasil yang sama dengan penelitian yang dilakukan oleh Farah dan Isnaini (2014) yang menyatakan bahwa komposisi gender 
berpengaruh signifikan terhadap corporate social responsibility. Namun demikian, Farah dan Isnaini (2014) melakukan penelitian dengan menghitung jumlah wanita di manajemen perusahaan, tanpa melakukan pemisahan di tiap bagian manajemen. Hal yang sama juga dilakukan oleh Bear et al. (2010) dan memberikan simpulan bahwa komposisi gender memiliki pengaruh signifikan terhadap corporate social responsibility. Berikut ini adalah pemaparan argument atau pembahasan dari hasil yang diperoleh untuk masing-masing sub variabel diversitas gender. Pertama, variabel diversitasgender_CEO berpengaruh signifikan terhadap corporate social responsibility.

Ibrahim dan Angelidis (2011) menyatakan bahwa direktur (CEO) wanita memberikan orientasi yang besar pada komponen corporate social responsibility. Didukung pula oleh Hyun et al. (2016) memberikan pernyataan bahwa proporsi wanita dalam direktur independen berhubungan positif dengan rating CSR perusahaan dan hubungan tersebut tergantung pada tingkat orientasi pasar konsumen perusahaan. Menurut Peneliti Catalyst dan HBS menyatakan bahwa perusahaan dengan dewan direksi dan pegawai yang didominasi wanita memberikan kontribusi sumbangan yang signifikan dan pemimpin wanita dapat memberikan perspektif yang luas atas keadilan dan distribusi sumber daya, dan selanjutnya komitmen perusahaan untuk kegiatan CSR menjadi semakin luas dan meningkatnya level sumbangan yang diberikan.

Kedua, variabel diversitasgender_CFO berpengaruh signifikan terhadap corporate social responsibility. CFO memiliki tanggung jawab untuk merumuskan strategi jangka menengah maupun jangka panjang terkait dengan bidang keuangan perusahaan, salah satunya adalah corporate social responsibility karena terkait dengan reputasi dan operasional perusahaan. Saat ini investor cenderung lebih tertarik dengan CSR dan menjadikannya sebagai salah satu penentu kriteria dalam berinvestasi. Dengan demikian semakin perusahaan memiliki reputasi atas CSR yang baik maka akan lebih mudah untuk memperoleh pendanaan dari investor, sehingga perusahaan akan memiliki resiko finansial yang lebih kecil. Adapun pengungkapan kegiatan CSR perusahaan tentu saja melibatkan keuangan perusahaan yang perlu dirumuskan dengan baik. Kedudukan wanita dalam CFO perusahaan memberikan pandangan yang berbeda. Menurut Croson dan Gneezy (2009), wanita memiliki kecenderungan untuk menolak resiko, sehingga dengan melakukan kegiatan CSR dapat menurunkan resiko finansial perusahaan. Selain itu, Croson dan Gneezy (2009) juga menyatakan bahwa wanita memiliki preferensi sosial yang lebih spesifik dan preferensi sosial yang lebih lunak. Dengan demikian, dimungkinkan mereka memiliki kecenderungan untuk melakukan kegiatan CSR.

Ketiga, variabel diversitasgender_komite audit (AC) berpengaruh signifikan terhadap corporate social responsibility. Wanita yang menjabat sebagai komite audit (AC) berpengaruh signifikan terhadap CSR. Argumen yang dapat diajukan dalam penelitian ini adalah dimungkinkan bahwa komite audit wanita cenderung lebih konservatif serta lebih beretika dibandingkan dengan komite pria (Jati, M. dan Sanjaya, 2013). Didukung pula oleh penelitian yang dilakukan oleh Novilia dan Nugroho (2016) yang mengatakan bahwa wanita memiliki sifat lebih berhati-hati dan kecenderungan untuk menghindari resiko serta memiliki standar etika yang tinggi. Komite audit memiliki tanggung jawab untuk membantu komisaris dalam menjalankan fungsinya yaitu mengawasi proses pelaporan keuangan, pelaksanaan audit dan lain-lain.

Keempat, variabel diversitasgender_komisaris (COM) tidak berpengaruh signifikan terhadap corporate social responsibility. Wanita yang berkedudukan 
sebagai komisaris dalam sampel penelitian ini tidak berpengaruh signifikan terhadap corporate social responsibility. Hal ini dimungkinkan karena di Indonesia masih sedikitnya jumlah wanita yang menjabat di posisi tersebut. Berdasarkan pada total 210 perusahaan yang menjadi sampel penelitian terdapat 149 perusahaan atau $71 \%$ yang tidak memiliki komisaris wanita dalam perusahaan, sedangkan perusahaan yang memiliki 3 komisaris wanita sejumlah hanya sejumlah 5 perusahaan. Hasil penelitian ini memberikan simpulan yang berbeda dengan Bear et al. (2010) yang melakukan penelitian pada perusahaan di Amerika yang memiliki komposisi gender yang tinggi. Dengan demikian, berdasarkan pada fenomena masih sedikitnya proporsi wanita dalam komisaris perusahaan menjadikannya kurang dapat diperbandingkan.

\section{Pengaruh Corporate Social Respon- sibility terhadap Nilai Perusahaan}

Tabel 2 memperlihatkan bahwa variabel corporate social responsibility berpengaruh terhadap nilai perusahaan dengan mengontrol variabel diversitas gender_CEO, diversitas gender_CFO dan diversitasgender_COM dengan tingkat signifikansi kurang dari 0.05 yang masingmasing adalah 0.0192, 0.0271 dan 0.0232, selain itu juga menghasilkan koefisien yang positif. Namun demikian, tidak berlaku pada pengaruh corporate social responsibility terhadap nilai perusahaan dengan mengontrol variabel diversitasgender_AC. Hasil penelitian ini didukung oleh Jo dan Harjoto (2011) yang menyatakan bahwa corporate social responsibility berpengaruh positif terhadap nilai perusahaan yang diukur dengan Tobin's q. Berdasarkan pada teori stakeholder bahwa perusahaan tidak hanya melakukan memiliki tanggungjawab dan kepentingan terhadap perusahaan sendiri, tetapi juga diharapkan dapat memberikan manfaat kepada stakeholdernya. Pada akhirnya akan menumbuhkan kepuasan stakeholder dan meningkatkan nilai perusahaan.

\section{Corporate Social Responsibility Me- mediasi Hubungan antara Diversitas Gender dengan Nilai Perusahaan}

Berdasarkan pada hasil output olah data penelitian, ditunjukkan bahwa variabel corporate social responsibility dapat memediasi hubungan antara variabel diversitas gender-CEO dan diversitasgender_CFO dan nilai perusahaan, sedangkan hubungan antara variabel diversitas gender-COM dan diversitasgender_AC dan nilai perusahaan tidak mampu dimediasi oleh corporate social responsibility.

Chief Executive Officer (CEO), Chief Chief Financial Officer (CFO), komisaris dan komite audit masing-masing memiliki peranan penting dalam perusahaan. CEO merupakan jabatan tertinggi dan pimpinan eksekutif dalam perusahaan. Menurut Nurrahmah dan Mutmainah (2010) keberhasilan perusahaan ditentukan oleh pemimpinnya dan terkait dengan gaya kepemimpinannya. Dezsö dan Ross (2012) yang mengungkapkan bahwa keberadaan wanita dalam top manajemen perusahaan dalam hal ini adalah CEO dapat memberikan informasi dan manfaat atas keberagaman sosial pada jajaran manajemen tingkat atas, selain itu dapat memotivasi wanita yang ada di manajemen tingkat menengah. Pada akhirnya, dapat meningkatkan kinerja manajerial dan kinerja perusahaan menjadi lebih baik. Selain itu wanita memiliki sensitivitas etis yang lebih besar dan menurut Schminke et al. (2005) dalam Ho et al. (2015) yang menyatakan bahwa seorang CEO harus menentukan norma etis dan menunjukkan pola kepemimpinan yang etis pula.

Keberadaan $\mathrm{CFO}$ dalam perusahaan bertanggung jawab dalam penyusunan laporan keuangan, selain itu juga melakukan analisis keuangan. Adapun yang melakukan pengambilan keputusan dan penentuan strategi perusahaan adalah 
CEO. Dengan demikian CEO dan CFO memiliki keterikatan yang cukup besar dalam menentukan kegiatan corporate social responsibility yang akan dilakukan oleh perusahaan. Hal tersebut berkaitan dengan kegiatan corporate social responsibility apa yang akan dilakukan serta dana yang akan dikeluarkan perusahaan. Segala bentuk kegiatan corporate social responsibility pada akhirnya akan diungkapkan dalam laporan tahunan perusahaan.

Pengungkapan tersebut dapat digunakan oleh pengguna informasi perusahaan pengambilan keputusan serta untuk menilai kepedulian perusahaan dalam kegiatan sosial.Kegiatan corporate social responsibility juga dapat berdampak pada berbagai aspek diantaranya adalah dapat membangun hubungan baik dengan pekerja dan masyarakat sekitar. Diungkapkan oleh Williams (2003) bahwa semakin besar jumlah wanita yang berada pada dewan perusahaan dan terlibat dalam kegiatan sosial yang lebih besar dibandingkan dengan perusahaan dengan jumlah wanita yang sedikit. Hal ini akan memberikan penilaian yang lebih bagi perusahaan, karena perusahaan tidak hanya mengutamakan hal-hal yang bersifat mendatangkan keuntungan tetapi juga yang bersifat sosial. Dengan demikian secara tidak langsung keberadaan wanita dalam CEO dan CFO dapat meningkatkan nilai perusahaan melalui kegiatan corporate social responsibility.

Berdasarkan pada KNKG (2006), komisaris bertugas dan bertanggungjawab mengawasi serta memberikan nasihat kepada direksi, namun tidak boleh turut serta dalam pengambilan keputusan operasional perusahaan.

Adapun komite audit bertugas membantu dewan komisaris untuk memastikan bahwa: i) laporan keuangan disajikan secara wajar sesuai dengan prinsip akuntansi yang berlaku umum, ii) struktur pengendalian internal perusahaan dilaksanakan dengan baik, iii) pelaksanaan audit internal dan eksternal dilaksanakan sesuai dengan standar audit yang berlaku, iv) tindak lanjut temuan hasil audit yang dilaksanakan oleh manajemen. Oleh karena itu, variabel corporate social responsibility tidak mampu memediasi hubungan antara komisaris dan komite audit dengan nilai perusahaan, hal ini dimungkinkan karena kegiatan corporate social responsibility dapat dikategorikan pengambilan keputusan operasional yang merupakan tanggungjawab direksi. Keterkaitan wanita yang berkedudukan sebagai komite audit dan komisaris dalam hubungan nya dengan corporate social responsibility dan nilai perusahaan didasari oleh argumen bahwa masih terdapatnya system patrilineal dalam budaya Indonesia. Sistem patrilineal merupakan system kekerabatan yang masih menganggap pria (garis keturunan ayah) yang memiliki kendali dan pengambil keputusan.Dengan demikian, berapapun jumlah wanita yang terdapat dalam jajaran komisaris dan komite audit perusahaan tidak dapat mempengaruhi corporate social responsibility. Dengan demikian, untuk variabel corporate social responsibility pun tidak dapat memediasi hubungan antara komisaris wanita dan komite audit wanita dengan nilai perusahaan.

\section{PENUTUP}

\section{Simpulan}

Simpulan yang dapat ditarik dalam penelitian ini adalah yang pertama, diversitas gender_CEO, diversitas gender_CFO dan diversitas gender_AC berpengaruh signifikan terhadap corporate social responsibility, sedangkan diversitas gender_COM tidak berpengaruh signifikan terhadap corporate social responsibility; kedua, corporate social responsibility berpengaruh terhadap nilai perusahaan dengan mengontrol variabel diversitas gender_CEO, diversitas gender_CFO dan diversitas gender_COM, selain itu juga menghasilkan koefisien yang positif. Namun demikian, corporate social 
responsibility tidak berpengaruh terhadap nilai perusahaan dengan mengontrol variabel diversitas gender_AC; ketiga, corporate social responsibility memediasi hubungan antara diversitas gender-CEO dan diversitasgender_CFO dan nilai perusahaan, sedangkan hubungan antara diversitas gender-COM dan diversitas gender_AC dan nilai perusahaan tidak mampu dimediasi oleh corporate social responsibility.

\section{Implikasi Manajerial}

Hasil penelitian ini belum sepenuhnya memberikan hasil yang sesuai dengan dugaan penelitian. Hal ini disebabkan karena masih sedikitnya diversitas gender yang menduduki jajaran dewan perusahaan di Indonesia. Walaupun secara teori, wanita memiliki beberapa kelebihan dibandingkan dengan pria. Perusahaan-perusahaan di Indonesia diharapkan dapat membaca peluang ini dengan berupaya meningkatkan keberadaan diversitas gender dalam dewan perusahaan.

\section{Keterbatasan dan Saran Penelitian Berikutnya}

Penelitian ini memiliki range waktu yang pendek, sehingga pada penelitian selanjutnya dapat memperpajang periode penelitian. Selain itu, dapat menggunakan teknik analisis data yang berbeda dan menambahkan variabel-variabel lain yang mungkin dapat memberikan pengaruh yang lebih besar, kaitamnya hubungan antara diversitas gender dengan nilai perusahaan seperti menambahkan variabel ukuran perusahaan sebagai variabel independen atau menjadi variabel kontrol.

\section{DAFTAR PUSTAKA}

Acker, J. (2004). Gender, Capitalism and Globalization. Working Paper. Critical Sociology. 30(1), 17-41.

Adams B. Renee,. Ferreira, D. (2004). Gender Diversity in the Boardroom. Working Paper. Stockholm School of Economics and Europian Corporate Governance Institute. November.

(2009). Women in the Boardroom and Their Impact on Governance and Performance. Journal of Financial Economics. Diunduh di http://ssrn.com/abstract=1107721 pada 11 April 2014.

Bear, S., Rahman, N., \& Post, C . (2010). The Impact of Board Diversity and Gender Composition on Corporate Social Responsibility and Firm Reputation. Journal of Business Ethics, 97(2), 207-221.

Boulouta, I. (2013). Hidden Connections : The Link Between Board Gender Diversity and Corporate Social Performance. Journal of Business Ethics, 113(2), 185-197.

Campbell, K. \& Antonio Minguez-Vera. (2008). Gender Diversity in the Boardroom and Firm Financial Performance. Journal of Business Ethics, 83, 435-451.

Carter, D. A., Frank D, Betty J.S, \& W. Gary Simpson. (2010). The Gender and Ethnic Diversity of US Boards and Board Committees and Firm Financial Performance. Corporate Governance: An International Review, 18(5), 396-414.

Chapple, L. \& Humphrey, E. J. (2013). Does Board Gender Diversity Have a Financial Impact? Evidence Using Stock Portfolio Performance. Journal of Business Ethics. 
Croson, R. \& U. Gneezy. (2009). Gender Differences in Preferences. Journal of Economic Literature, 47(2), 127.

Dahlsrud, A. (2006). How Corporate Social Responsibility is Defined: an Analysis of 37 Definitions. Corporate Social Responsibility and Environmental Management (in press). Wiley InterScience.

Dezsö, Cristian L., \& David Gaddis Ross. (2012). Does female representation in top management improve firm performance? A panel data investigation. Strategic Management Journal, 33(9), 1072-1089.

Dominguez, L.R. Maria, I. Sanchez, G. Alvarez, I.G. (2012). Explanatory Factors of the Relationship Between Gender Diversity and Corporate Performance. Europian Journal of Law Economics, 33(3), 603-620.

Dutta, Probal. Bose, S. (2008). Gender Diversity in the Boardroom and Financial Performance of Commercial Banks: Evidence from Bangladesh. MPRA Paper No. 7916.

Farah, M. \& Ratna I. (2014). Board Diversity and Gender Composition on Corporate Social Responsibility and Firms Reputation in Indonesia. Jurnal Manajemen dan Kewirausahaan, 16(1), 1-8.

Feijoo, B.F., Romero, S. \& Ruiz, S. (2012). Does Board Gender Composition Affect Corporate Social Responsibility Reporting? International Journal of Business and Social Science, 3(1), 31-38.
Freeman, E. R \& Phillips, A. R. (2002). Stakeholder Theory : A Libertarian Defense. Business Ethics Quarterly, 12(3).

Ghozali, I. (2006). Aplikasi Analisis Multivariate Dengan Program SPSS. Semarang: Badan Penerbit Undip.

Gregory, A., Rajesh Tharyan, \& Julie Whittaker. (2012). Corporate social responsibility and company value. UK: University of Exeter.

Hafsi, T., \& Turgut, G. 2013. Boardroom Diversity and its Effect on Social Performance: Conceptualization and Empirical Evidence. Journal of Business Ethics, 112(3), 463-479.

Hayes, F. Andrew. (2009). "Beyond Baron and Kenny : Statistical Mediation Analysis in the New Millenium". Communication Monograph. 76(4), 408-420.

Ho, S.S.M., Li, A.Y., Tam, K., \& Zhang, F.F. (2015). CEO Gender, Ethical Leadership, and Accounting Conservatism. Journal of Business Ethics, 127(2), 351-370.

http://www.catalyst.org/media/newcatalyst-study-links-more-womenleaders-greater-corporate-socialresponsibility

Huang, H.W. Yan, Y. Fornaro, J. \& Elshahat, A. (2011). Market Reaction to Audit Committee Director's Gender: Evidence From US-Trade Foreign Firms. Diakses di

http://www.epublications.bond.edu. au/ijbf/vol8/iss1/4, pada 22 April 2014. 
Hyun, E., Yang, D., Jung, H., \& Hong, K. (2016). Women on boards and corporate social responsibility. Sustainability, 8(4), 300.

Jati, M. \& Sanjaya. (2013). Pengaruh karakteristik personal komite audit terhadap real earnings management. Universitas Atma Jaya Jogyakarta.

Jo, Hoje, \& Maretno A. Harjoto. (2011). Corporate governance and firm value: The impact of corporate social responsibility. Journal of Business Ethics, 103(3), 351-383.

Jurkus, F.M. Park, J.C. \& Woodard, S.L. (2005). Gender Diversity and Firms Performance: Environmentally Reliant?. Working Paper. Louisiana Tech University, Ruston.

Kang, Helen. Mandy Cheng. Sidney J. Gray. (2007). Corporate Governance and Board Composition: Diversity and Independence of Australian Boards. Journal Compilation, 15(2), 194-207.

Krishnan, H.A., \& Park, D. (2005), A Few Good Women on Top Management Teams, Journal of Business Research, 58(12), 17121720.

Marshall, J. (2007). The Gendering of Leadership in Corporate Social Responsibility. Journal of Organizational Change Management, 20(2), 165-181.

Nguyen, Hoa, Faff, R. (2006). Impact of Board Size and Board Diversity on Firm Value : Australian Evidence. Corporate Ownership and Control, 4(2).
Nielsen, S. \& Huse. M. (2010). Women Directors' Contribution to Board Decision-Making and Strategic Involvement: The Role of Equality Perception. European Management Review, 7, 16-29.

Novilia, O. \& Nugroho, P. I. (2016). Pengaruh Manajemen Puncak Wanita Terhadap Manajemen Laba. Jurnal Dinamika Akuntansi, Keuangan dan Perbankan, 5(1), 27-45.

Nurrahmah, K. \& Mutmainah, S. (2013). Analisis Pengaruh Diversitas Gender Terhadap Voluntary Corporate Governance Disclosure dalam Laporan Tahunan Perusahaan. Diponegoro Journal of Accounting, 2(1), 1-15.

Preacher, J. K. \& Hayes, F. A. (2004). SPSS and SAS Procedures for Estimating Indirect Effects in Simple Mediation Models. Behavior Reseacrh Methods, Instrumens, \& Computers, 35(4), 717-731.

Puspaningsih, A., \& Rahmawati, I.P. (2017). Pengaruh Corporate Social Responsibility Terhadap Nilai Perusahaan dengan Prosentase Kepemilikan Manajemen Sebagai Variabel Moderating. Jurnal Aplikasi Bisnis (13), 9.

Rose, C. (2007). Does Female Board Representation Influence Firm Performance? The Danish evidence. Journal Compilation,15(2), 404-413. 
Rouf, A. (2011). The Relationship Between Corporate Governance and Value of the Firm in Developing Countries : Evidence from Bangladesh. International Journal of Applied Economicsand Finance.

Salim, D. (2012). Do Women in Top Management Affect Firm Performance? Evidence from Indonesia. MPRA Paper. No. 38743 .

Shafique, Y., Idress, S., \& Yousaf, H. (2014). Impact of Boards Gender Diversity on Firms Profitability: Evidence from Banking Sector of Pakistan. Europian Journal of Business and Management, 6(7), 296-307.

Smith, N., Smith, V., \& MetteVerner. (2005). Do Women in Top Management Affect Firm Performance? A Panel Study of 2500 Danish Firms.Working Paper Iza Discussion Paper no.1708.

Sri H., \& Dewi, K. W. (2009). Faktorfaktor yang Mempengaruhi Nilai Perusahaan pada Perusahaan yang Terdaftar di Bursa Efek Malaysia dan Bursa Efek Indonesia. Jurnal Siasat Bisnis, 13(2), 173-183.

Williams, R. (2003). Women on Corporate Boards of Directors and their Influence on Corporate Philanthropy. Journal of Business Ethics, 42, 1-10. 